\title{
Assessment of soil erosion risk severity using GIS, remote sensing and RUSLE model in Oued Laou Basin (north Morocco)
}

\author{
Omayma Amellah*1, Karim el Morabiti ${ }^{1}$ \\ ${ }^{1}$ Department of Geology, Faculty of Sciences, Abdelmalek Essaâdi University, Tetouan, Morocco \\ * Omayma Amellah, amellahoumaima@gmail.com, ORCID iD: https://orcid.org/0000-0002-1177-2466
}

Received: 23.02 .2021

Accepted: 23.09.2021

Associated editor: Ł. Mendyk

\section{Keywords}

Erosion prone area

Erosion model

RUSLE

Remote sensing

GIS

Rif region

\begin{abstract}
Soil loss by lateral flow is a critical bother in the Oued Laou basin due to the steepness of its landscape relief and the considerable deference altitudinal between the upstream and downstream area. Those predispositions highly increase soil vulnerability to the risk of erosion indeed; tones of sediment are transported each year, causing significant damages regarding structures and waterworks such as siltation. For this reason, this work focus on the merging of remote sensing techniques, GIS, and the Revised Universal Soil Loss (RUSLE) Equation to quantitatively evaluate soil erosion severity as well as highlight the most erosion-prone areas in the Oued Laou basin, Northwestern Morocco. Accordingly, the study site area was arranged into six soil erosion risk categories: very slight (25.3\%), slight (12.4\%), moderate (40.5 \%), intense (12.2\%), very intense, (5\%) and severe (4.6\%). Moderate to severe soil loss rates that are correlated to abrupt slopes defined most of the basin area. In addition to the spatial distribution of soil severity classes over the study area, the average annual soil erosion rate was estimated to be $31.5 \mathrm{t} \mathrm{ha}^{-1}$ year-1 $^{-1}$ in the Oued Laou watershed. The latter amount was compared to many previous studies that have been carried out in the surrounding basins based on RUSLE or other techniques to validate the model accuracy.
\end{abstract}

\section{Introduction}

Soil erosion by water is a worldwide phenomenon that causes land degradation (Vaezi et al., 2011; Ganasri and Ramesh, 2015; Ostovari et al., 2017) by exacerbating nutrient loss (Pal and Chakrabortty, 2019). It not merely leads to land degradation and loss of soil nutrients but also intensifies the recurrence of floods, droughts, landslides, and other hazards (Munodawafa, 2007; Park et al., 2011; Arnhold et al., 2014; Rickson, 2014; Zeng et al., 2017). It is a natural process, and its severity and extent depend on diverse environmental parameters, including climate, topography, soil, land cover, rainfall, and interactions between them (Mutua et al., 2006; Butt et al., 2010; Thomas et al., 2017; Kayet et al., 2018). In most cases, however, this process is strongly intensified by human activities (deforestation, agricultural practices), which is referred to human-induced or accelerated erosion (Dotterweich et al., 2013; Świtoniak, 2014; Van Oost et al., 2003).

Soil loss by surface flow is a serious issue in the Oued Laou watershed, typically in the upstream part with consequential effects on the downstream flooding, crop production, and waterworks structures. Many factors and practices aggravate the severity and intensifying the process of erosion, especially in the middle and south areas. Steep topography, grazing, poor agricul- tural management, forest fire, planned burning, some irrational human activities may also trigger land cover degradation and pronouncing the amount of soil loss. Runoff or water erosion risks become more important during rainy seasons, which readily alter, detach, and convey the soil, as well as contribute to the sedimentation trouble in the downstream waterworks, such as bridges and reservoir siltation.

Soil erosion risk estimation has been a concern to scientists since the 1930s (Renard et al 1994; Dutta et al., 2015) to predict and recognize control erosion practices. Quantitative methods are the most required for assessing how swiftly soil abrades from its initial location (Park et al., 2011). Different techniques have been implemented to assess soil loss by water at diverse levels such as global, regional, and local (Terranova et al., 2009; Jarađiűnas et al., 2020). Several models have also been developed to quantify the soil loss rate (Poesen et al., 2003; Gayen et al., 2019). These models are classified into empirical, semi empirical, and physical-process-based models (Pan and Wen, 2014). The most widely used is the Universal Soil Loss Equation (USLE), which was created in 1978 by the United States Department of Agriculture (USDA) to predict the quantity of the eroded material durably (Abdo and Salloum, 2017). It is an empirical algorithm evaluating long-term means of sheet and rill erosion, using plot data gathered in the eastern USA (Wischmeier and Smith, 1965). 
A recent version of USLE was presented by (Renard et al., 1997), which is known as The Revised Universal Soil Loss Equation (RUSLE). It has been utilized widely to assess soil loss amount at a sustainable basis from hillslopes in vast extent investigations (Panagos et al., 2015; Teng et al., 2016; Teng et al., 2018). In the last years, many scientists all over the world subserved RUSLE. Some of them aligned to the catchment to estimate the amount of soil loss related to cultivating practices (Prasannakumar et al., 2012; Dissanayake et al., 2018; Tessema et al., 2020).

RUSLE provides the possibility to quantify soil erosion rate at the plot extent, besides it simulates the spatial distribution of soil loss over a field (Renard et al., 1997; Youe-Qing et al., 2008). The use of geospatial technique and RUSLE model is an advantageous combination, and a widely used method owing to its simpleness and applicability over large-scale areas with better reliability and cost-effectiveness (Millward and Mersey, 1999; Wang et al., 2003; Angima et al., 2003 Lu et al., 2004; Krishna Bahadur, 2009; Zhang et al., 2010; Demirci and Karaburun, 2012; Pradeep et al., 2015). The present research aims to applicate the RUSLE model combined with remote sensing and GIS techniques in order to estimate the amount of soil erosion rates at the Oued Laou catchment of North Morocco.

\section{Materials and methods}

\subsection{Study site}

The Oued Laou study site is a coastal watershed situated at the NW part of Morocco, at $45 \mathrm{~km}$ of Tetouan city, on the provincial borders of Tetouan and Chefchaouen (Amellah et al., 2020)
(Fig. 1 and Fig. 2). Covering an area around $928 \mathrm{~km}^{2}$, the south part of the site under study is mostly mountainous, marked by abrupt slopes and steep reliefs: the northern part is mainly flat at the central area and gently hilly at the borders, the altitude range between 0 and $2122 \mathrm{~m}$ above sea level. The climate is subhumid Mediterranean with $700 \mathrm{~mm}$ annual average rainfall with humid, relatively cold winter and dry, warm summer. The majority of precipitation occurs between November and March. The annual average temperature is $18.6^{\circ} \mathrm{C}$.

\subsection{Data requirement}

The set of data requirements necessary for implementing the RUSLE model were provided by a diversity of sources, including the following: (i) the average annual rainfall data from 1969 to 2018 collected from the Loukkos Hydraulic Basin Agency (LHBA), including five hydrometric stations in the study area. (ii) The soil database was provided by the Provincial Directorate of Water, Forests, and the Fight Against Desertification (PDWFFAD), including soil map, soil characteristics, and measurements. (iii) Digital Elevation Model (DEM) with a resolution $5 \mathrm{~m}$ cell size generated using GIS tools from digitized contours of the official $1 / 25000$ topographic maps. (vi) Landsat 8 remotely sensed images (August 2016).

\subsection{RUSLE}

The RUSLE model is an empirical equation that quantifies the average annual soil erosion in $\mathrm{t} \mathrm{ha}^{-1} \mathrm{year}^{-1}$. Indeed, estimates the mean annual soil erosion (A) per unit area, rainfall erosivity (R), soil erodibility (K), slope length and slope steepness (LS),

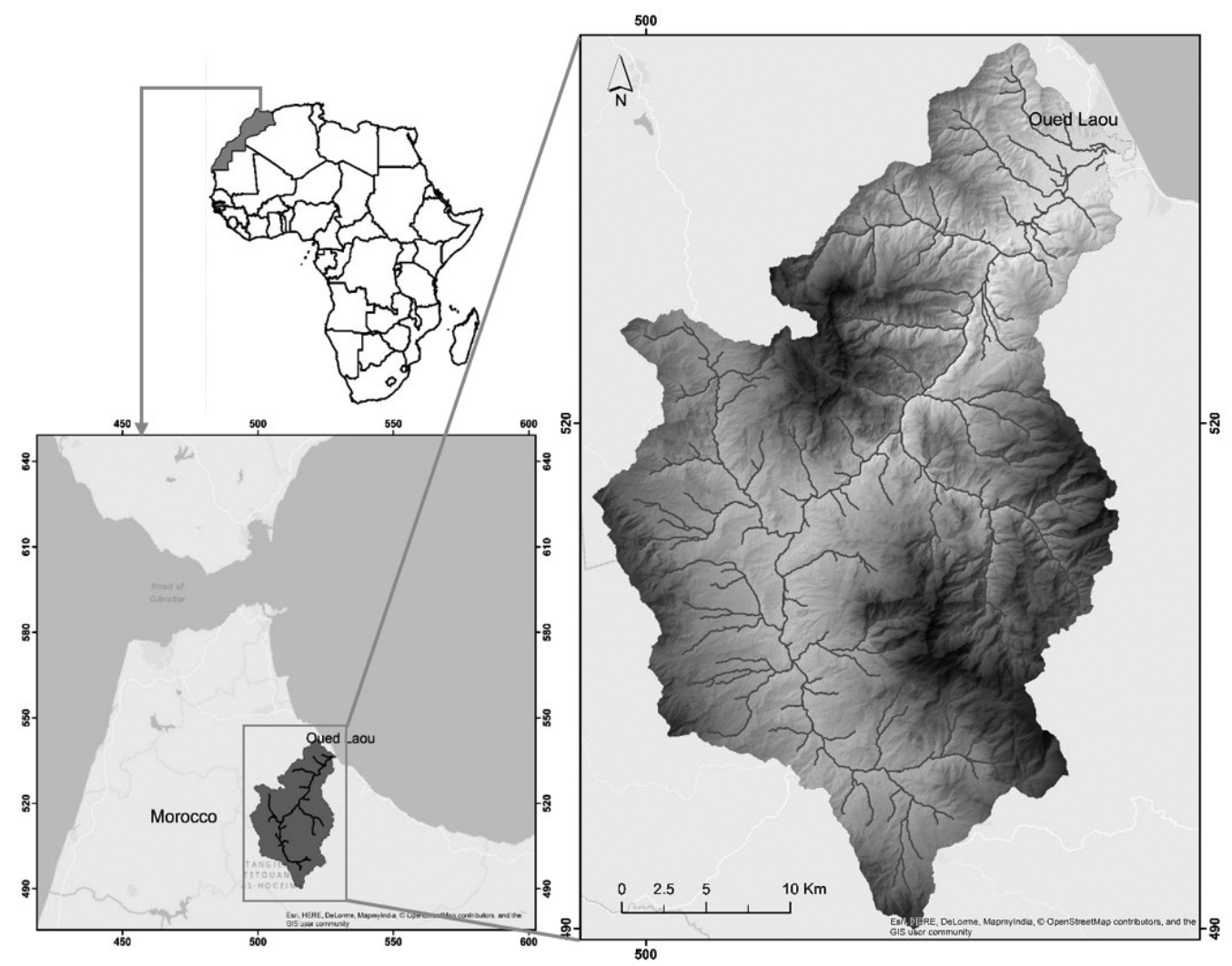

Fig. 1. Location of the study area 

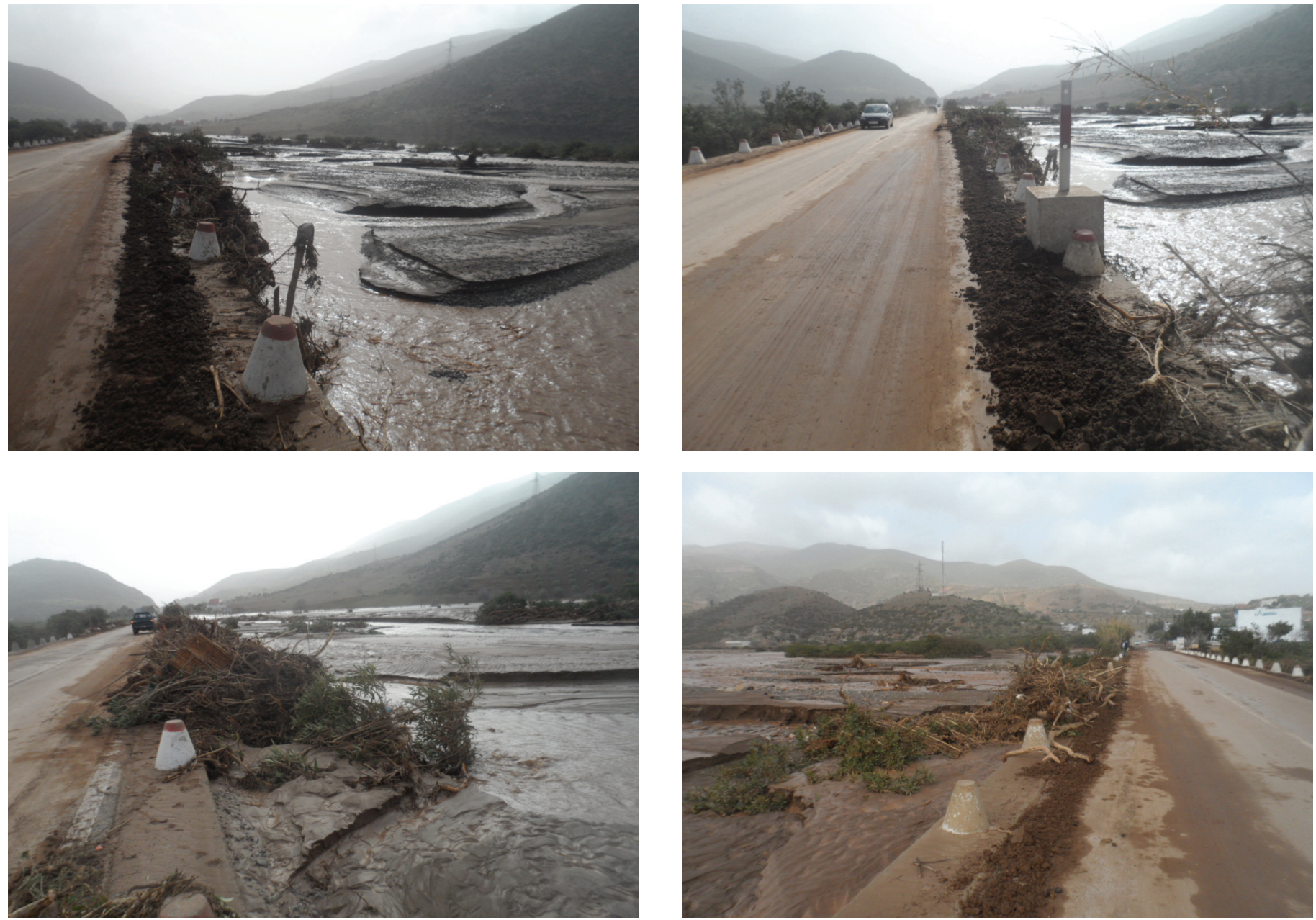

Fig. 2. Examples of the repercussion caused by water erosion processes at Oued Laou Basin: the eroded sediment carried by the flow precipitates downstream of the basin, causing the siltation of the bridge while modifying the course of the flow, the overflow of the bridge by water and sediment, and sometimes the interruption of the road circulation

land cover-management (C), and support practice (P). These factors were spatially executed based on GIS algorithms and remote sensing processes from the data collected previously. For the objective of generating raster data sets of each factor, two software were necessarily required (Arc GIS 10.2 and ENVI platforms). Then the five factor layers were multiplied each other following the RUSLE equation to quantify the average annual soil loss of the watershed and produce the soil severity classes (Fig. 3) as follows:

\section{$A=R \cdot K \cdot L S \cdot C \cdot P$}

Where A ( ha $^{-1}$ year-1 $\left.^{-1}\right)$ t the average annual soil loss per unit area, $\mathrm{R}\left(\mathrm{MJ} \mathrm{mm} \mathrm{ha} \mathrm{m}^{-1} \mathrm{~h}^{-1}\right.$ year-1): rainfall/ runoff erosivity factor, $\mathrm{K}\left(\mathrm{t} \mathrm{h} \mathrm{MJ} \mathrm{Jm}^{-1} \mathrm{~mm}^{-1}\right.$ : soil erodibility factor signifies the soil loss rate of specific soil rainfall erosivity per unit measured in a standard plot, L slope length factor, S slope steepness factor, C crop management factor, and P support practices factor.

Fig. 3. Working Methodology

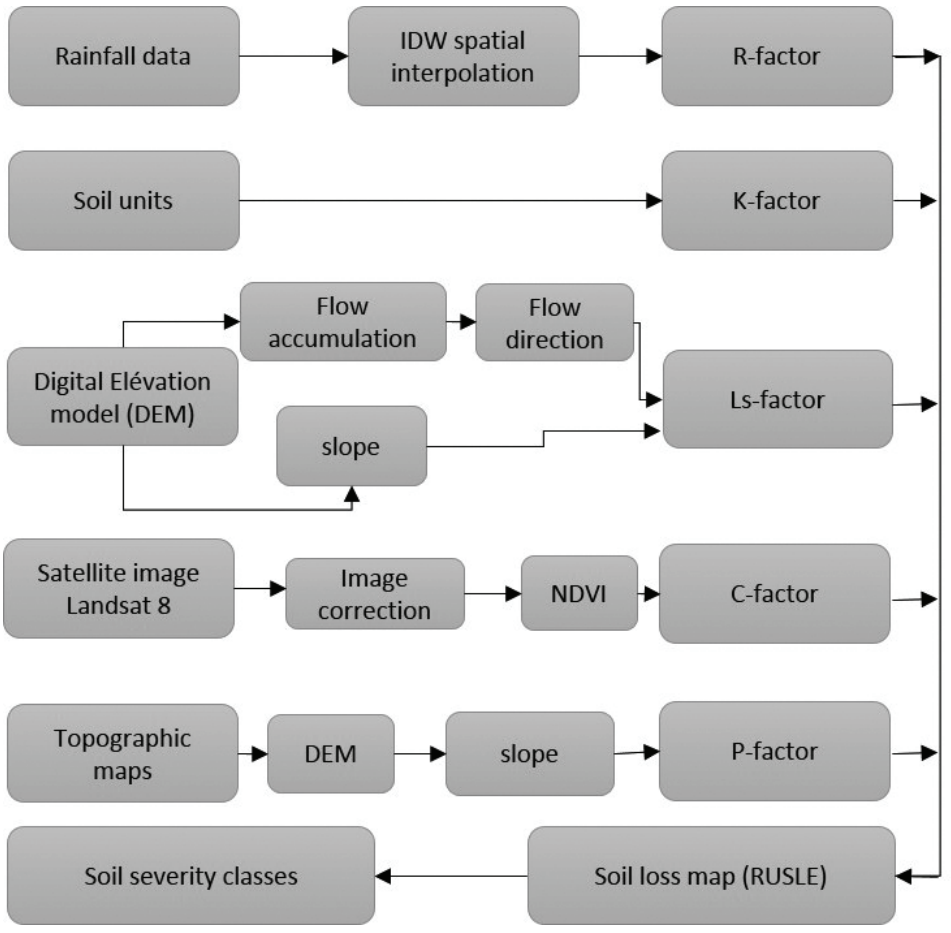




\subsection{RUSLE parameter estimation}

\subsubsection{Rainfall erosivity Factor (R)}

Rainfall erosivity (R) is an indicator of the potential of rainfall intensity to induce soil loss by detaching and transporting soil particles. Its computation requires continuous and detailed rainfall observations (Ganasri and Ramesh, 2016). The R-factor is a complex process that highly depends on the amount, energy, duration, intensity, size of raindrops, the pattern of precipitation, and the resulting runoff rate (Farhan and Nawaiseh, 2015). This erosivity factor is likely to be the most controlling for soil loss in many research studies (Wischmeier and Smith, 1978). Rainfall erodibility can be obtained from the intensity of the precipitation for the particular period of the area under consideration (Renard et al., 1997; Kouli et al., 2009). However, estimating the $R$-factor is commonly challenging in most regions in the world due to the scarcity of high-resolution rainfall data (Thomas et al., 2018). Regarding this work, the rainfall erosivity factor for this basin was produced from the average annual rainfall (mm) data observations at the level of five stations during the period between 1969 and 2018. Only two stations are inside the study area, Koudiat Kourriren and Bab Taza, the Ben Karrich, Torreta, and Amzal stations are outside surrounding the basin (Table 1).

\subsubsection{Soil erodibility factor (K)}

Soil erodibility $(\mathrm{K})$ indicates the inherent susceptibility of the soil to be eroded. This mechanism depends on the mineralogical, morphological, physical, and chemical attributes of the soils. The K-factor signifies the quantity of soil loss per unit of

Table 1

Meteorology stations and there corresponding average annual rainfall.

\begin{tabular}{lllll}
\hline $\begin{array}{l}\text { Meteorological } \\
\text { station }\end{array}$ & $\mathrm{X}$ & $\mathrm{Y}$ & $\mathrm{Z}$ & $\begin{array}{l}\text { average annual } \\
\text { rainfall }(\mathrm{mm})\end{array}$ \\
\hline Koudiat Kourriren & 520 & 528.9 & 30 & 633 \\
Bab Taza & 518.6 & 495.2 & 350 & 750 \\
Ben Karrich & 495.7 & 545.6 & 20 & 656 \\
Torreta & 502.4 & 550.8 & 8 & 635.6 \\
Amzal & 492.9 & 549.5 & 20 & 652.4 \\
\hline
\end{tabular}

rainfall erosive energy, referring to a plot of the clean bare soil of $22 \mathrm{~m}$ long and 9\% slope (Brady and Weil, 2012; Biswas and Pani, 2015). Regarding the physical characteristics, some soils are more susceptible to erosion than others (Miheretu and Yimer, 2018; Radziuk and Świtoniak, 2021). The chemical characteristics are also playing an important role in materials eroding. The most characteristics affecting $\mathrm{K}$ are soil structure, organic content, texture, and permeability of the soil profile (Kouli et al., 2008; Balasubramani et al., 2015; Pal and Chakrabortty, 2019). The soil erodibility factor is calculated based on the soil type details. In-situ data measurements of the soil, and assigning the K-factor values is time-consuming, expensive, and requires specific equipment. Thus, the soil units map of the basin was extracted from the digital soil map (2000) that has been implemented based on the soil survey of (2000) made by the National Institute of Agricultural Research (NIAR) (Table 2). Consequently, the type of dataset available in the area understudy determines the selected approach (Yesuph and Dagnew, 2019). K factor was estimated based on the soil composition amount of silts, clay, sand, and organic matter in each soil unit, and then the values of the $\mathrm{k}$ factor transformed into raster layer using GIS tools.

\subsubsection{Topographic factor (LS)}

The topographic factor (LS) is the sensitive element of RUSLE for estimating soil erosion (Renard et al., 1997). It expresses the compound influence of slope gradient (S) and slope length (L), which powerfully affects the soil particles' transportation. Besides, it identifies the ratio of soil erosion per surface unit on a field to the relative loss from a $22.13 \mathrm{~m}$ long plot with a 9\% slope gradient under similar circumstances. The LS parameter augments slope gradient and slope length (Fig. 4). LS factor indicates the gradient responsible for the velocity of the flow. The steeper the land slope, the higher the velocity and erosive potential of runoff (Wischmeier and Smith, 1978; Renard et al., 1997; Yesuph and Dagnew, 2019). Plenty of approaches are available to LS factor calculation in the literature. In order to produce LS factor for this work, through the GIS raster calculator related to map algebra toolbox, the equation developed by (Moore and Wilson, 1992) was chosen and applied as follows:

Table 2

Soil types and their corresponding area in $\mathrm{km}^{2}$ and $\%$

\begin{tabular}{llll}
\hline Soil type & Area $\left(\mathrm{km}^{2}\right)$ & Area (\%) & $\begin{array}{c}\text { Estimated K value } \\
\left(\mathrm{t} \mathrm{ha} \mathrm{MJ}^{-1} \mathrm{~mm}^{-1}\right)\end{array}$ \\
\hline Slightly evolved Fersiallitic soils and Raw minerals & 116.30 & 12.52 & 0.15 \\
Burnished and Raw mineral soils & 54.70 & 5.80 & 0.21 \\
Fersiallitic and Slightly evolved soils & 40.02 & 4.31 & 0.3 \\
Raw mineral and Slightly evolved soils & 125.99 & 13.56 & 0.35 \\
Burnished and Slightly evolved soils & 165.04 & 17.76 & 0.4 \\
Slightly evolved soils & 157.29 & 16.93 & 0.3 \\
Calcimagnesic, Fersiallitic and Raw miniral soils & 277.93 & 29.91 & 0.46 \\
\hline
\end{tabular}


$L S=\left(\frac{Q_{a} M}{22.1}\right)^{0.6} \times\left(\frac{(\sin (\text { slope }) \times 0.01745)}{0.09}\right)^{1.3}$

Where

$L S=$ Topographic factor;

$Q_{a}=$ Grid of Flow Accumulation;

$M=$ Grid size.

\subsubsection{Crop management factor (C)}

The $C$ factor determines the influence of management practices and cropping on soil loss rates. It analyses the effects of management potentials and conservation plans (Jobin et al.,
2018). This identifies the amount of soil loss related to cropland under typical parameters to the relative loss of a clean-tilled, continuous fallow (Wischmeier and Smith, 1978). Recently, satellite images have been widely utilized to calculate the $C$ factor. This work as well made use of remotely sensed images to calculate the $C$ factor based on the vegetation index (NDVI) (Fig. 5) following the (Van Der Knijff, 2000):

$C=\exp \left[-\alpha \times \frac{N D V I}{\beta-N D V I}\right]$

Where

$\alpha \& \beta$ are the variables controlling the NDVI-C curve, with $\alpha=2$; $\beta=1$.

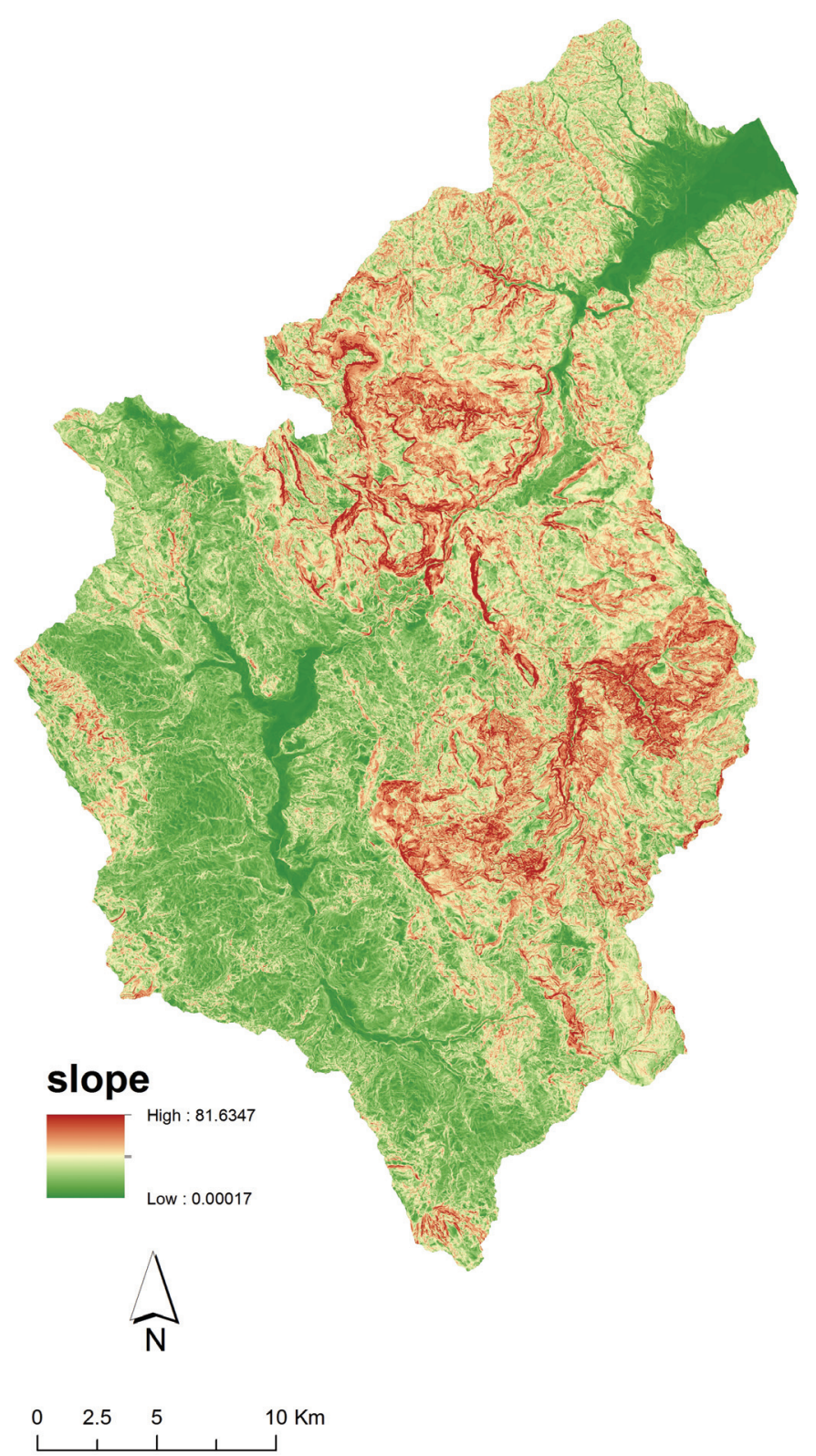

Fig. 4. Slope distribution map in (\%) of the study basin

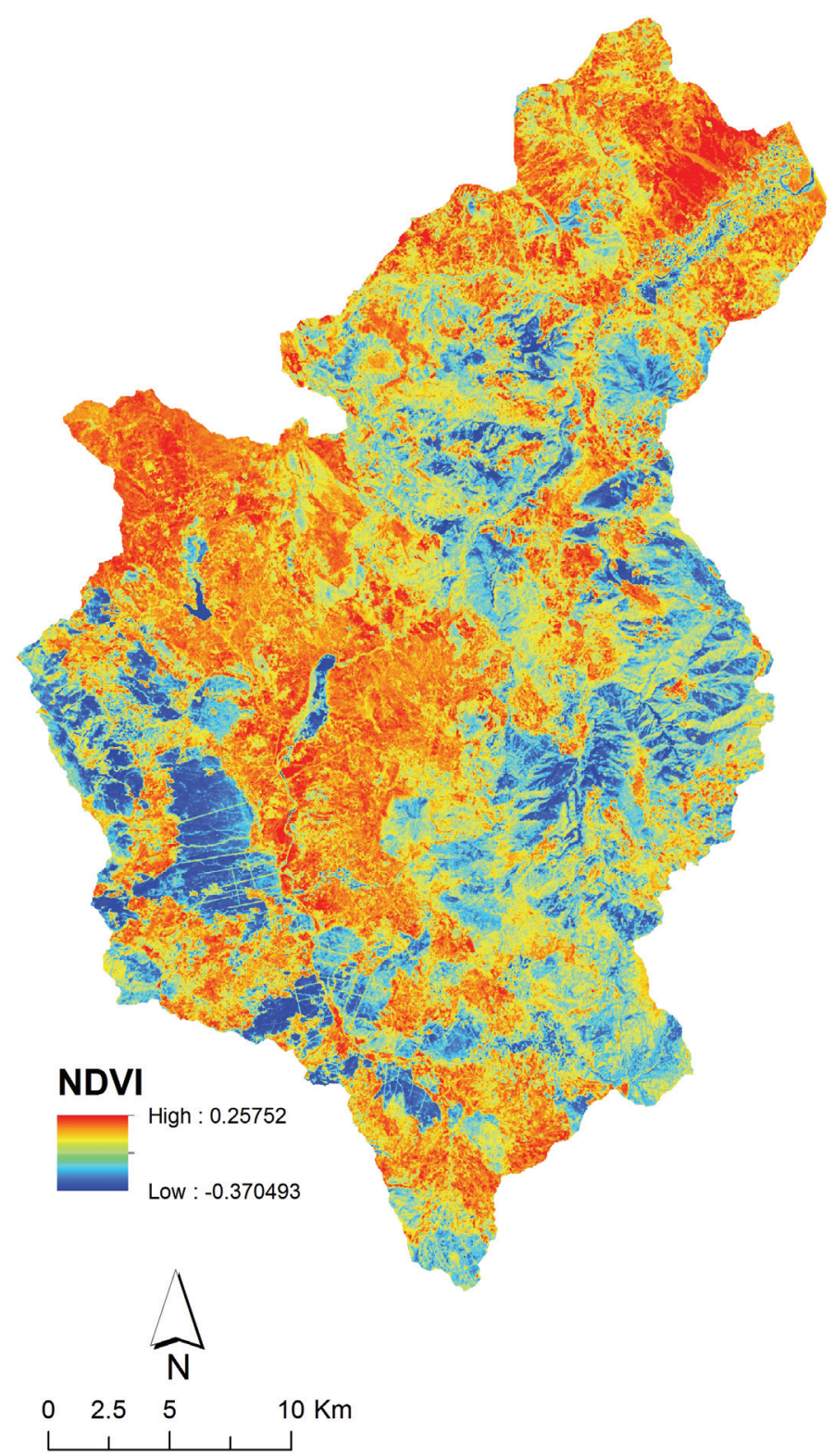

Fig. 5. NDVI map of the watershed 


\subsubsection{Conservation support practice factor $(P)$}

Soil and water conservation factor $\mathrm{P}$ is the percentage of soil loss with specific support practices to the depletion loss of up and downslope tillage (Pal and Chakrabortty, 2019; Pandey et al., 2007; Wischmeier and Smith, 1978; Renard et al., 1997). The lower the $\mathrm{P}$ factor value, the more efficient the conservation practice is in reducing soil loss. The supporting practice factor (P) was calculated referring to the method of cultivation. It is computed as the relationship between terracing and slope in paddy land and is calculated based on the relationship between contour and slope in cultivated fields (Pan and Wen, 2014). The values obtained are between 0 and 1 . The 0 value signifies that the field is not susceptible to soil loss, while the value 1 means that the site is not subject to either soil or water conservation measures.

\section{Results and discussion}

The assessment of soil loss risk levels at catchment extent is crucial for durable land use management. The five erosioncontrolling raster's, R, K, LS, C, and P factors, were combined to estimate and assess annual soil loss erosion based on the raster calculator tool of the GIS interface. Annual average rainfall data were used to compute rainfall erosivity ( $R$-factor). The latter varied within the range from 347 to $413 \mathrm{MJ} \mathrm{mm} \mathrm{ha-1} \mathrm{h}^{-1}$. Precipitation increases from low areas (Kourriren station) to high altitude areas (Chefchaouen and Babtaza). And therefore, high soil loss is anticipated as the (R) factor increases in the central and southern parts of the study area while it decreases in the north. (Fig. 6a).

The LS-factor values range between 0-20 as the slope and flow accumulation increase. The lowest LS values are located in the down slope lands, reflecting the slope effect on the LS outcomes. Its spatial distribution is shown in the $L S$ factor of (Fig. 6b), illustrating that the lowest $L S$ values located along the valley of Oued Laou (LS $<10$ topographically, this part of the study area is not susceptible to water erosion). The highest LS values are seen in the complex Dorsale landforms of the watershed with steep relief, especially in the middle and south.

The erodibility factor (K) values in the watershed area swing from 0.1 to 0.46 proving the susceptibility of soils (low to medium) and their vulnerability to erosion. Indeed, the spatial distribution of the K-factor seen in (Fig. 6c) shows that only $29 \%$ of the watershed shows a low erodibility, represented by the class of fersialitic, little evolved, and raw mineral soils with $\mathrm{K}$ varying from 0.1 to 0.2 . (30\%) the site shows a strong erodibility with a high level of $\mathrm{K}$ ranging between 0.3 and 0.46 . The highest values of the $K$-factor are distributed in the middle of the study area where soils are thin and slopes are steep.

The $C$-factor calculated based on equation (3) varies from 0.37 to 0.68 . The spatial distribution of the $C$-factor is illustrated in (Fig. 6d) showing that the remotely sensed datasets (NDVI) make it possible to predict $C$-factor with high performance. It highlights that most high relief areas over the basin covered with vegetation, which also shows significant protection and helps minimize soil erosion.

P-factor (Fig. 6e): nearly all $\mathrm{P}$ values tend towards 1 over the entire watershed area, except for the downstream river where cultivated areas are limited. The absence of soil conservation practices can interpret this value.

The factors of the RUSLE model in the area under study were represented through raster layers in the GIS platform. Those layers were multiplied together following the equation to calculate the average soil erosion by mean of the raster calculator tool of the GIS software. The outcome layer of this process was then classified into six soil loss categories: very slight, slight, moderate, intense, very intense, and severe. In the final soil erosion map of the watershed (Fig. 7), soil erosion rate below 10 ton $\mathrm{ha}^{-1} \mathrm{MJ}^{-1}$ was defined as very slight erosion, while those $>30 \mathrm{t} \mathrm{ha}^{-1}$ year $^{-1}$ were defined as severe. The values between very slight and severe erosion were classified further as slight, moderate, intense and very intense erosion areas (Table 3).

The soil loss estimation has been carried out in many watersheds of the Rif. Comparing the results of this work with the results obtained by the other authors allows relatively to validate the outcomes of this approach. For instance, (Moukhchane et al., 1998) estimated an average soil loss of $17 \mathrm{tha}^{-1}$ year-1 in $^{-1}$ the Rif area. An average of $38.7 \mathrm{t} \mathrm{ha}^{-1} \mathrm{year}^{-1}$ was estimated by (Ait Brahim et al., 2003) in the Nakhla watershed. In the Khmiss wadi watershed (Khali Issa et al., 2014) found an average of $37 \mathrm{t}$ ha $^{-1}$ year $^{-1}$. Also in the watershed of Tlata and that of Oued Sania (Dahman, 1994; Tahiri et al., 2014) found an average loss of around $32.5 \mathrm{t} \mathrm{ha}^{-1}$ year $^{-1}$ and $47.18 \mathrm{t} \mathrm{ha}^{-1}$ year $^{-1}$ respectively.

Many scientists applied many techniques to estimate the soil loss rates over different areas of the Rif. Including the work of (Moukhchane et al., 1998) that quantifies the erosion rate in the Nakhla basin of $39.6 \mathrm{t} \mathrm{ha}^{-1}$ year-1 using the 137Cs method. (Merzouki, 1992) estimated an average of $47.2 \mathrm{t} \mathrm{ha}^{-1}$ year $^{-1}$ using the bathymetry method in the Telata basin. Based on remotely sensed analyses (Bonn, 1998) has estimated $39 \mathrm{t} \mathrm{ha}^{-1}$ year-1 of $^{-1}$ soil loss for the Tleta basin. Using the same technique (Damnati et al., 2006) found an average of 26,6 tha $\mathrm{hear}^{-1}$ for Raouz basin. (Zouagui and Benmansour, 2012) have found an average of $23 \mathrm{t} \mathrm{ha}^{-1}$ year $^{-1}$ in the Moulay Bouchta basin.

According to many research studies that have been carried out using RUSLE model, for instance, in the Oued Sahla watershed, (Central Rif) an average of $22 \mathrm{t} \mathrm{ha}^{-1}$ year-1 $^{-1}$ was estimated by (Sadiki et al., 2009). $55 \mathrm{t} \mathrm{ha}^{-1}$ year $^{-1}$ was found at the Oued Boussouab catchment by (sadiki et al., 2004) (Eastern Rif) and an average annual rate of $25.77 \mathrm{t} \mathrm{ha}^{-1}$ year $^{-1}$, in Araba Ayacha watershed was calculated by (Ouallali et al., 2017). The application of RUSLE or other methods to estimate soil loss in the Rif watersheds ranges from $17 \mathrm{t} \mathrm{ha}^{-1}$ year $^{-1}$ to $55 \mathrm{t} \mathrm{ha}^{-1}$ year-1. Most are between $20 \mathrm{t} \mathrm{ha}^{-1}$ year $\mathrm{r}^{-1}$ and $40 \mathrm{t} \mathrm{ha}^{-1}$ year $^{-1}$. The $31.5 \mathrm{t} \mathrm{ha}^{-1}$ year $^{-1}$ obtained in this work falls within this range, which relatively validates the results of this technique. 
(a)

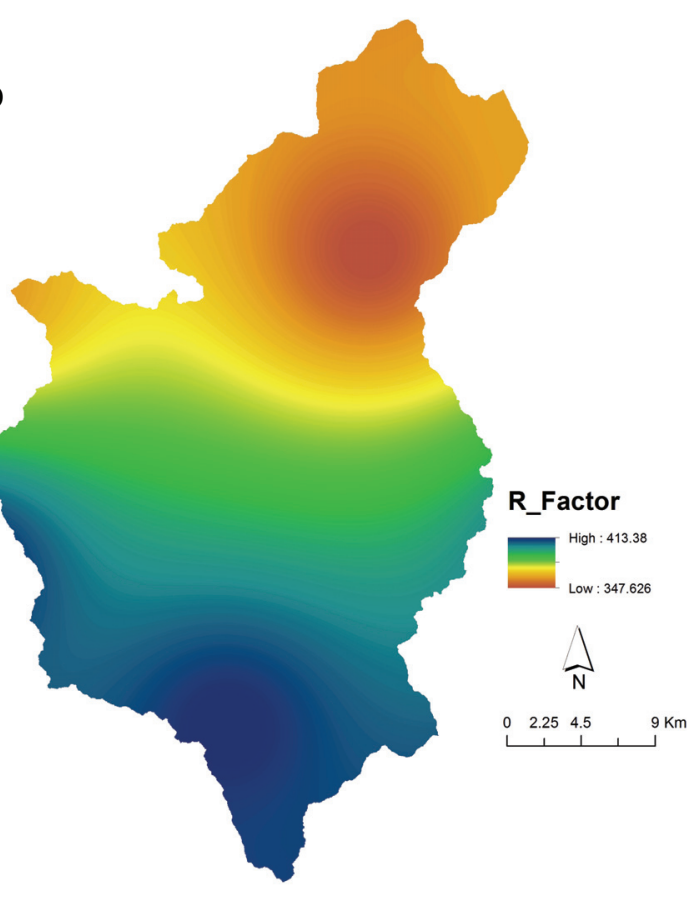

(c)

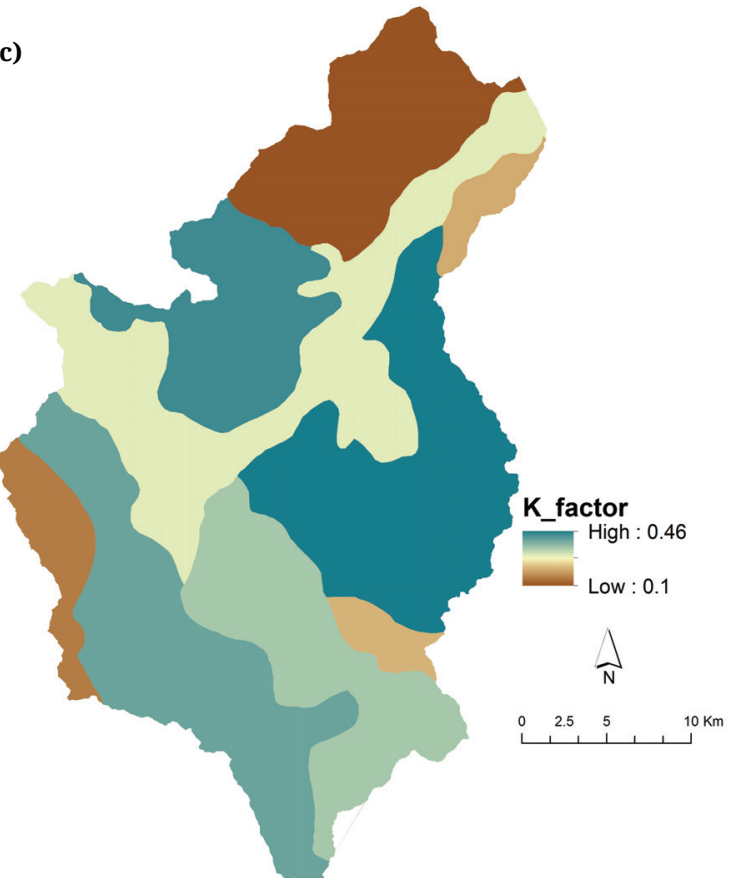

(e)

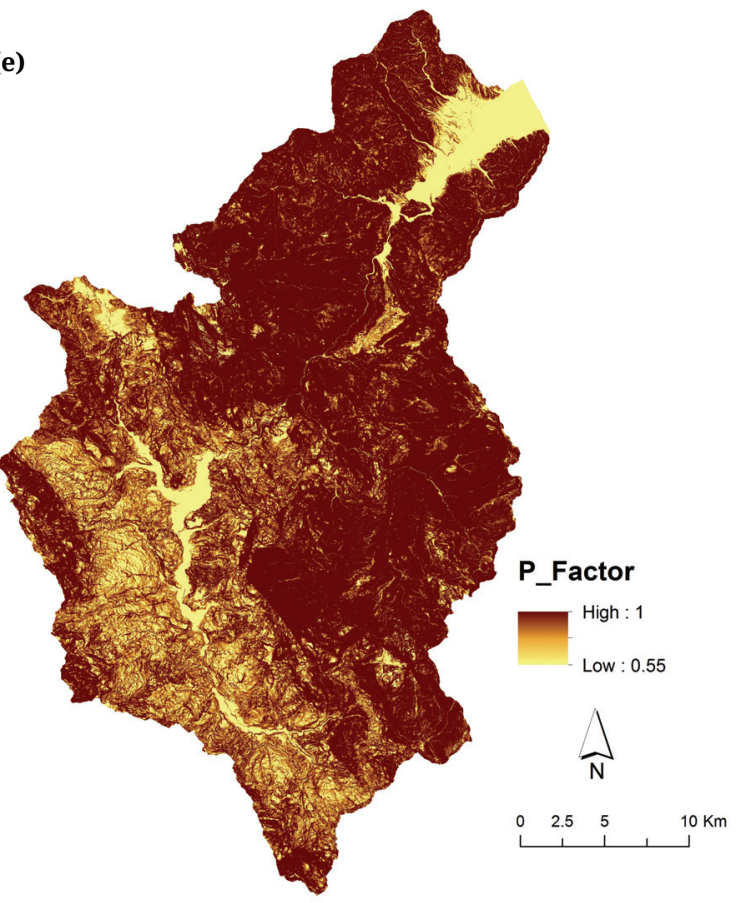

(b)

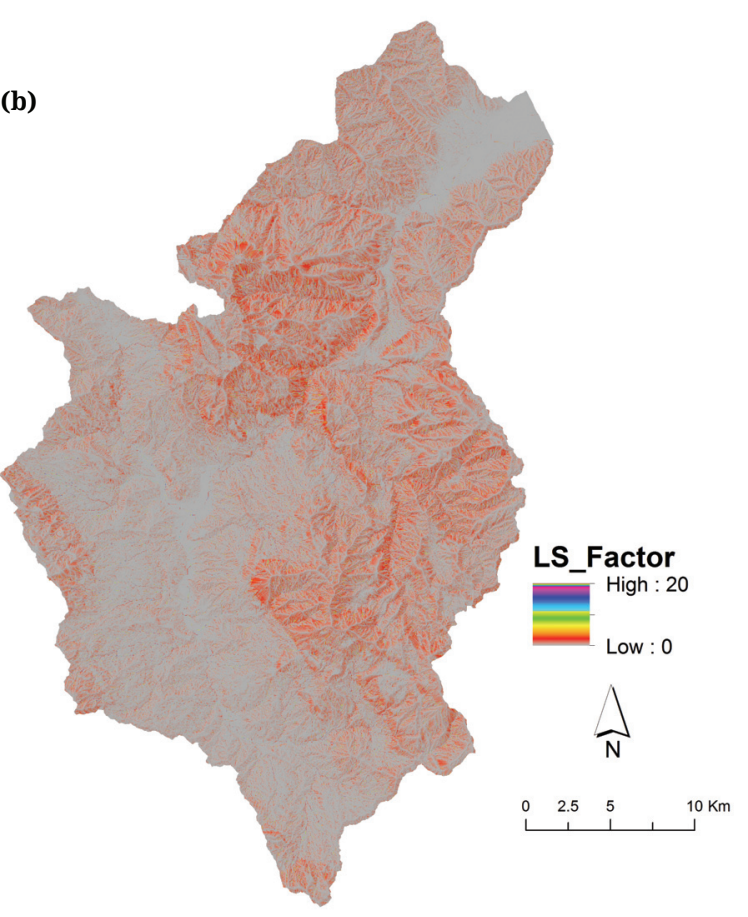

(d)

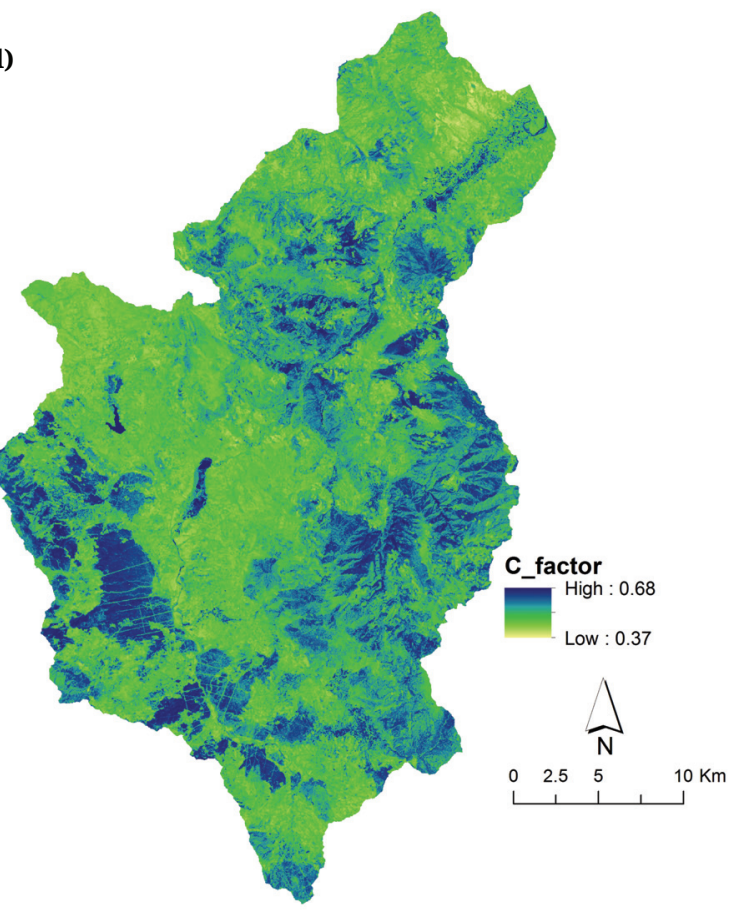

Fig. 6. Spatial distribution of RUSEL factors: (a) map of rainfall erosivity R-factor, (b) map of slope length and steepness LS-factor, (c) map of soil erodibility K-factor, (d) crop management C-factor, (e) map of support practice P-factor 
(a)

soil loss( t ha-1 yr-1)

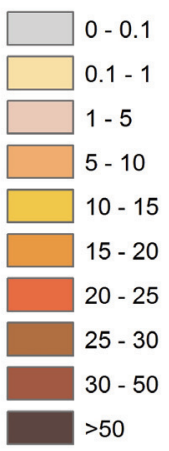

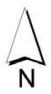

$\begin{array}{llll}0 & 2.5 \quad 5 \quad 10 \mathrm{Km}\end{array}$

Table 3

Soil loss severity classes with hazard levels and their corresponding area (in \% and ha) and annual soil loss (in t ha-1 year-1) $^{-1}$ (b)

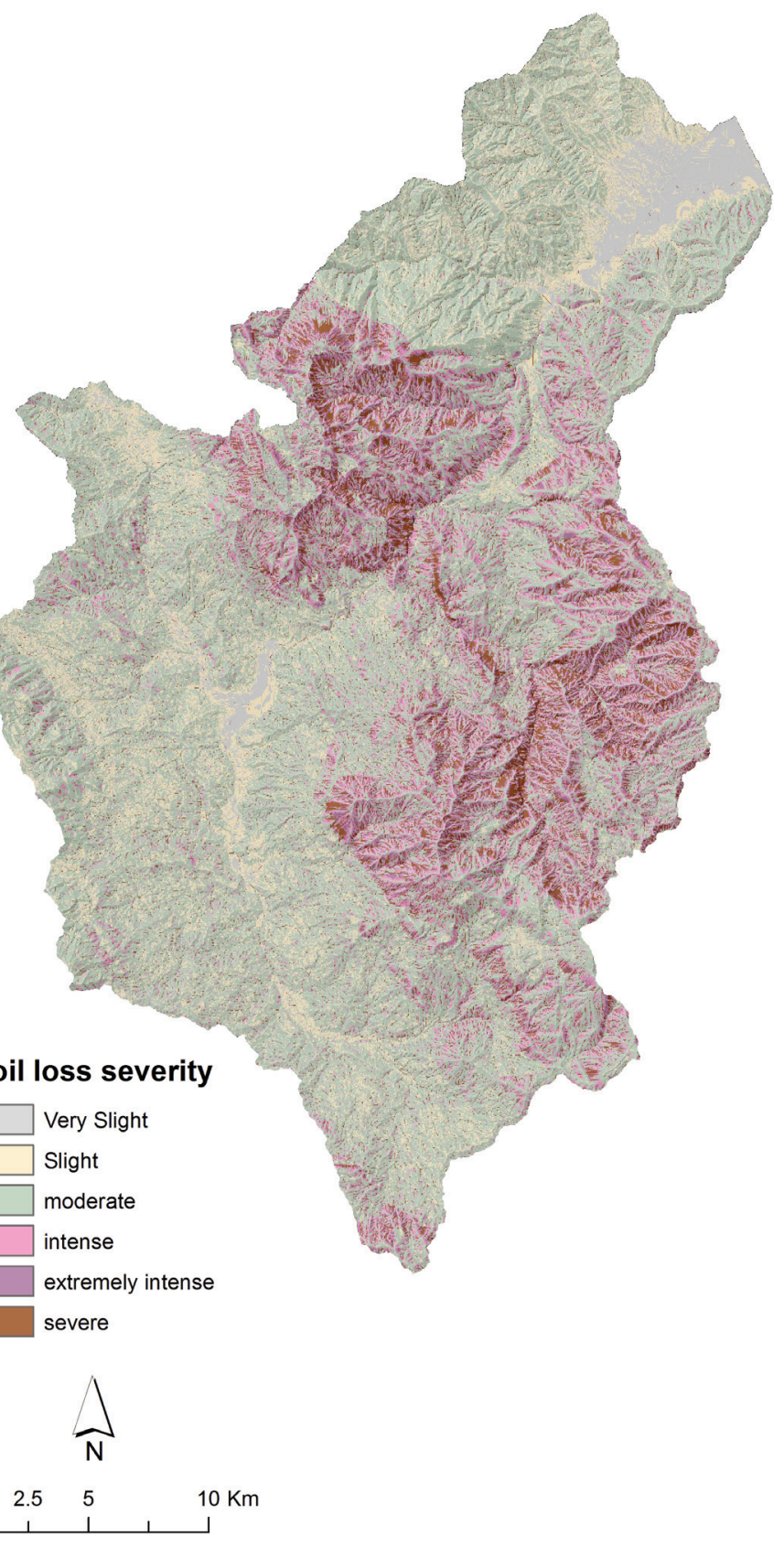

Fig. 7. Spatial distribution of Soil erosion potential (A) calculated using the RUSLE method. (a) Soil loss in $\mathrm{t} \mathrm{ha}^{-1}$ year $^{-1}$, (b) soil severity classes

\begin{tabular}{lllll}
\hline $\begin{array}{l}\text { Soil loss severity } \\
\left(\mathrm{t} \mathrm{ha}^{-1} \text { year }^{-1}\right)\end{array}$ & $\begin{array}{l}\text { Severity } \\
\text { classes }\end{array}$ & Area $\left(\mathrm{km}^{2}\right)$ & Area (ha) & Area (\%) \\
\hline $0-0.1$ & Very slight & 23447.7 & 23447.7 & 25.3 \\
$0.1-1$ & Slight & 11478.15 & 11478.15 & 12.4 \\
$1-10$ & Moderate & 37539.63 & 37539.63 & 40.5 \\
$10-20$ & Intense & 11225.61 & 11225.61 & 12.2 \\
$20-30$ & Very intense & 4417.38 & 4417.38 & 5 \\
$30-50<$ & Severe & 4228.83 & 4228.83 & 4.6 \\
\hline
\end{tabular}




\section{Conclusions}

This work illustrates the implementation of an empirical soil erosion model called RUSLE combined with the Geographic Information System in order to quantify soil loss potential areas at the level of the Oued Laou catchment. The reason behind opting for this soil erosion model is that relatively simple, easy to interpret physically, requires fewer datasets, and can be developed using readily available inputs for areas specifically at high erosion risk. Quantitative estimation of soil losses, obtained from the combined GIS and the RUSLE empiric model, classified basin area into six soil erosion risk levels: very slight (25.3\%), slight (12.4\%), moderate (40.5\%), intense (12.2\%), very intense (5\%) and severe (4.6\%). With: (i) $62 \%$ of the watershed area is prone to high risk of water erosion with annual average losses of 31.5 t ha $^{-1}$ year $^{-1}$. (ii) The slight and very slight losses are mainly located at the north of the study site on lowland slopes, low precipitation, and a minimum of erodibility. (iii) Maximum losses are found in the middle of the watershed coincide with abrupt slopes and consequently, high erosion risk estimated by the RUSLE erosion model in this basin area. This case study can only be a starting point for further work in this direction given the need and its importance in supporting land use planning, decision-making, and implementing erosion control practices in the area.

\section{Acknowledgements}

The authors gratefully acknowledge the ERASMUS+ and the Civil Engineering Faculty (Mühendislik Fakültesi) of Cumhuriyet University for the help regarding image treatment Pr. Önder Gürsoy and Rutkay Atun.

\section{References}

Abdo, H., Salloum J., 2017. Mapping the soil loss in Marqya basin: Syria using RUSLE model in GIS and RS techniques. Environmental Earth Sciences 76, 1-10. https://doi.org/10.1007/s12665-017-6424-0

Aït Brahim, L., Sossey Alaoui, F., Siteri, H. et al., 2003. Quantification of soil loss in the Nakhla watershed (northern Rif). Sécheresse - Science et changements planétaires 14(2), 101-106.

Amellah, O., El Morabiti, K., Ouchar Al-djazouli, M., 2020. Spatialization and assessment of flood hazard using 1D numerical simulation in the plain of Oued Laou (north Morocco). Arabian Journal of Geosciences 13, 635. https://doi.org/10.1007/s12517-020-05592-4

Angima, S.D., Stott, D.E., O’Neill, M.K., Ong, C.K., Weesies, G.A., 2003. Soil erosion prediction using RUSLE for central Kenyan highland conditions. Agriculture Ecosystems \& Environment 97, 295-308.

Arnhold, S., Lindner, S., Lee, B., Martin, E., Kettering, J., Nguyen, T.T., 2014. Conventional and organic farming: soil erosion and conservation potential for row crop cultivation. Geoderma 219-220, 89-105. https:// doi.org/10.1016/j.geoderma.2013.12.023

Balasubramani, K., Veena, M., Kumaraswamy, K., Saravanabavan, V., 2015. Estimation of soil erosion in a semi-arid watershed of Tamil Nadu (India) using revised universal soil loss equation (RUSLE) model through GIS. Model Earth Systems and Environment 1(3), 10.

Bonn, F., 1998. La spatialisation des modèles d'érosion des sols à l'aide de la télédétection et des SIG : possibilités, erreurs et limites. Sécheresse 9(3), 185-192.
Brady, NC., Weil, RC., 2012. The nature and properties of soils. Pearson education, New Delhi.

Butt, M.J., Waqas, A., Mahmood, R. CSHRG., 2010. The combined effect of vegetation and soil erosion in the water resource management. Water Resources Management 24(13), 3701-3714. http://dx.doi. org/10.1007/s11269-010-9627-7

Damnati, B., Chatt, A., Hamani, M. et al., 2006. L'érosion hydrique et sa quantification par le radioélément $137 \mathrm{Cs}$ au niveau du bassin versant du barrage Raouz (Région de Tanger-Tétouan). TANCA-01. Workshop sur les techniques analytiques, nucléaires et conventionnelles, et leurs applications, Rabat, p38.

Demirci, A., Karaburun, A., 2012. Estimation of soil erosion using RUSLE in a GIS framework: a case study in the buyukcekmece lake watershed, northwest Turkey. Environmental Earth Science 66, 903-913.

Dhman, H., 1994. Utilisation des SIG et des télédétections dans l'étude de l'érosion hydrique: application au bassin versant de Tleta. Mémoire de troisième cycle, ENFI, Salé, 120 p.

Dissanayake, D., Morimoto, T., Ranagalage, M., 2018. Accessing the soil erosion rate based on RUSLE model for sustainable land use management: a case study of the Kotmale watershed, Sri Lanka Modeling. Earth Systems and Environment 5, 291-306. https://doi.org/10.1007/ s40808-018-0534-x

Dotterweich, M., Stankoviansky, M., Minár J., Koco, Š., Papčo P., 2013. Human induced soil erosion and gully system development in the Late Holocene and future perspectives on landscape evolution: The Myjava Hill Land, Slovakia. Geomorphology 201, 227-245.

Dutta, D., Das S., Kundu, A., Taj, A., 2015. Soil erosion risk assessment in Sanjal watershed, Jharkhand (India) using geo-informatics, RUSLE model and TRMM data. Modeling Earth Systems and Environment, 1, 37. https://doi.org/10.1007/s40808-015-0034-1

Farhan, Y., Nawaiseh, S., 2015. Spatial assessment of soil erosion risk using RUSLE and GIS techniques. Environmental Earth Sciences 74, 4649-4669. https://doi.org/10.1007/s12665-015-4430-7

Ganasri, B.P., Ramesh H., 2015. Assessment of soil erosion by RUSLE model using remote sensing and GIS - A case study of Nethravathi Basin. Geoscience Frontiers, XXX, 1-9.

Gayen, A., Saha, S., Pourghasemi, H.R., 2019. Soil erosion Assessment using RUSLE model and its Validation by FR probability model. Geocarto International 35(15), 1750-1768. https://doi.org/10.1080/101060 49.2019.1581272

Jarašiūnas, G., Świtoniak, M., Kinderienè, I., 2020. Dynamics of slope processes under changing land use conditions in young morainic landscapes, Western Lithuania. International Agrophysics 34, 43-55. https://doi.org/10.31545/intagr/116404

Jobin, T., Sabu, J., Thrivikramji, K.P., 2018. Assessment of soil erosion in a monsoon-dominated mountain river basin in India using RUSLE-SDR and AHP. Hydrological Sciences Journal 63(4), 542-560, https://doi. org/10.1080/02626667.2018.1429614

Kayet, N., Pathak, K., Chakrabarty, A., Sahoo, S., 2018. Evaluation of soil loss estimation using the RUSLE model and SCS-CN method in hillslope mining areas. International Soil and Water Conservation Research 6, 31-42. https://doi.org/10.1016/j.iswcr.2017.11.002

Khali Issa, L., Raissouni, A., Moussadek, R., et al., 2014. Mapping and assessment of water erosion in the Khmiss Watershed (North Western Rif, Morocco). Current Advances in Environmental Science, 4, 119-130.

Kouli, M., Soupio, P., Vallianatos, F., 2009. Soil erosion prediction using the revised universal soil loss equation (RUSLE) in a GIS framework Chania, northwestern Crete, Greece. Environmental Geology 57, 483-497.

Krishna Bahadur, K.C., 2009. Mapping soil erosion susceptibility using remote sensing and GIS: a case of the Upper Nam Wa Watershed, Nan Province, Thailand. Environmental Geology 57, 695-705.

Lu, D., Mausel P., Batistella, M., Moran, E., 2004. Comparison of landcover classification methods in the Brazilian Amazonia basin. Photogrametric Engineering and Remote Sensing 70, 723-731. 
Merzouki, T., 1992. Diagnostic de l'envasement des grands barrages marocains. La Revue marocaine du Génie civil 38, 46-50.

Miheretu, B.A., Yimer, A.A., 2018. Estimating soil loss for sustainable land management planning at the Gelana sub-watershed, northern highlands of Ethiopia. International Journal of River Basin Management 16(1), 41-50.

Millward, A.A, Mersey, J.E., 1999. Adapting the RUSLE to model soil erosion potential in a mountainous tropical watershed. Catena 38, 109-129.

Moukhchane, M., Bouhlassa, S., Chalouan, A., 1998. Approche cartographique et magnétique pour l'identification des sources de sédiments : cas du bassin versant Nakhla (Rif, Maroc). Sécheresse 3(9), 227-232.

Munodawafa, A., 2007. Assessing nutrient losses with soil erosion under different tillage systems and their implications on water quality. Physics and Chemistry of the Earth Parts A/B/C 32, 1135-1140, https:// doi.org/10.1016/j.pce.2007.07.033

Mutua, B.M., Klik, A., Loiskandl W., 2006. Modelling soil erosion and sediment yield at a catchment scale: the case of Masinga catchment, Kenya. Land Degradation \& Development 17(5), 557-570. https://doi. org/10.1002/ldr.753

Ostovari, Y., Ghorbani-Dashtaki, S., Bahrami, H.A., Naderi, M., Dematte, J.A.M., 2017. Soil loss prediction by an integrated system using RUSLE, GIS and remote sensing in semi-arid region. Geoderma Regional 11, 2-36. https://doi.org/10.1016/j.geodrs.2017.06.003

Ouallali, A., Moukhchane, M., Aassoumi, H., Berrad, F., Dakir, I., 2017. Evaluation and mapping of water erosion rates in the watershed of the Arbaa Ayacha River (Western Rif, Northern Morocco). Bulletin de l'Institut Scientifique, Rabat, Section Sciences de la Terre, 2016, 38, 65-79.

Pal, S.C., Chakrabortty, R., 2019. Simulating the impact of climate change on soil erosion in sub-tropical monsoon dominated watershed based on RUSLE, SCS runoff and MIROC5 climatic model. Advances in Space Research 64, 352-377. https://doi.org/10.1016/j.asr.2019.04.033

Pan, J., Wen, Y., 2014. Estimation of soil erosion using RUSLE in Caijiamiao watershed. China Natural Hazards, 71, 2187-2205. https://doi. org/10.1007/s11069-013-1006-2

Panagos, P., Borrelli, P., Poesen, J., Ballabio, C., Lugato, E., Meusburger, K., et al., 2015. The new assessment of soil loss by water erosion in Europe. Environmental. Science and Policy 54, 438-447.

Pandey, A., Chowdary, V.M., Mal, B.C., 2007. Identification of critical erosion prone areas in the small agricultural watershed using USLE, GIS and remote sensing. Water Resources Management 21(4), 729-746.

Park, S., Oh, C., Jeon, S., Jung, H., Choi, C., 2011. Soil erosion risk in Korean watersheds, assessed using the revised universal soil loss equation. Journal of Hydrology 399, 263-273. https://doi.org/10.1016/ j.jhydrol.2011.01.004

Poesen, J. Nachtergaele, J. Verstraeten, G., Valentin, C., 2003. Gully erosion and environmental change: importance and research needs. Catena 50, 91-133.

Pradeep, G.S., Ninu Krishnan, M.V., Vijith, H., 2015. Identification of critical soil erosion prone areas and annual average soil loss in an upland agricultural watershed of Western Ghats, using analytical hierarchy process (AHP) and RUSLE techniques. Arabian Journal of Geosciences 8, 3697-3711.

Prasannakumar, V., Vijith, H., Abinod, S., Geetha, N., 2012. Estimation of soil erosion risk within a small mountainous sub-watershed in Kerala, India, using revised universal soil loss equation (RUSLE) and geoinformation technology. Geoscienes Frontiers 3, 209-215, https://doi. org/10.1016/j.gsf.2011.11.003

Radziuk, H., Świtoniak, M., 2021. Soil erodibility factor (K) in soils under varying stages of truncation. soil science annual, 72, 1-8. https://doi. org/10.37501/soilsa/134621

Renard, K., Foster, G.R., Wessies, G.A., Porter, J.P., 1994. RUSLE-Revised universal soil loss equation. Journal of Soil and Water Conservation 46, 30-33. 2.
Renard, K.G., Foster, G.R., Weesies, G.A., McCool, D.K., Yoder, D.C. (1997). Predicting soil erosion by water: a guide to conservation planning with the revised universal soil loss equation (RUSLE). USDA Agricultural Handbook, No. 703.

Rickson, R.J., 2014. Can control of soil erosion mitigate water pollution by sediments?. Science of the Total Environment., 468-469, 1187-1197. https://doi.org/10.1016/j.scitotenv.2013.05.057

Sadiki, A., Bouhlassa, S., Auajjar, J. et al., 2004. Utilisation d'un SIG pour l'évaluation et la cartographie des risques d'érosion par l'Equation universelle des pertes en sol dans le Rif oriental (Maroc): cas du bassin versant de l'Oued Boussouab. Bulletin de l'Institut Scientifique, Rabat, section Sciences de la Terre, $n^{\circ} 26$, 69-79.

Sadiki, A., Faleh, A., Zezerze, J.L. et al., 2009. Quantification de l'erosion en nappe dans le bassin versant de l'Oued Sahla, Rif occidental Maroc. Cahiers géographiques 6, 59-70.

Świtoniak, M., 2014. Use of soil profile truncation to estimate influence of accelerated erosion on soil cover transformation in young morainic landscapes, North-Eastern Poland. Catena 116, 173-184.

Tahiri, M., Tabyaoui, H., El Hammichi, F. et al., 2014. Evaluation et Quantification de l'Erosion et la Sédimentation à Partir des Modèles RUSLE, MUSLE et Déposition Intégrés dans un SIG: Application au Sous-Bassin de l'Oued Sania (Bassin de Tahaddart, Rif nord occidental, Maroc). European Journal of Scientific Research 125(2), 157-178.

Teng, H.F., Viscarra Rossel, A.V., Shi, Z., Behrens, T., Chappell, A., Bui, E., 2016. Assimilating satellite imagery and visible-near infrared spectroscopy to model and map soil loss by water erosion in Australia. Environmental Model and Software 77, 156-167.

Teng, H., Liang, Z., Chen, S., Liu, Y., Rossel, R.A.V., Chappell, A., Yu, W. \& Shi, Z., 2018. Current and future assessments of soil erosion by water on the Tibetan Plateau based on RUSLE and CMIP5 climate models. Science of the Total Environment 635, 673-686.

Terranova, O., Antronico, L., Coscarelli, R., Iaquinta, P., 2009. Soil erosion risk scenarios in the Mediterranean environment using RUSLE and GIS: An application model for Calabria (southern Italy). Geomorphology 112, 228-245.

Tessema, Y.M., Jasińska J., Yadeta L.T., Świtoniak M., Puchałka R., Gebregeorgis E.G., 2020. Soil Loss Estimation for Conservation Planning in the Welmel Watershed of the Genale Dawa Basin, Ethiopia. Agronomy 10, 777. https://doi.org/10.3390/agronomy10060777

Thomas, J., Joseph, S. Thrivikramji, K.P., 2018. Assessment of soil erosion in a tropical mountain river basin of the southern Western Ghats, India using RUSLE and GIS. Geoscience Frontiers 9, 893-906 . http:// dx.doi.org/10.1016/j.gsf.2017.05.011

Vaezi, A.R., Sadeghi, S.H., 2011. Evaluating the RUSLE model and developing an empirical equation for estimating soil erodibility factor in a semi-arid region. Spanish Journal of Agricultural Research 9(3), 912-923.

Van Oost, K., Van Muysen, W., Govers, G., Heckrath, G., Quine, T.A., Poesen, J., 2003. Simulation of the redistribution of soil by tillage on complex topographies. European Journal of Soil Sciences 54, 63-76.

Vander Knijff, J.M., Jones R.J.A., Montanarella, L., 2000. Soil erosion risk assessment in Europe. European SoilBureau, European Communities, EUR19044EN, 32p.

Wang, G., Gertner, G., Fang, S., Anderson, A.B., 2003. Mapping multiple variables for predicting soil loss by geo- statistical methods with TM images and a slope map. Photogrametric Engineering Remote and Sensing 69, 889-898.

Wischmeier, W.H., Smith, D.D., 1978. Predicting rainfall erosion losses. A guide to conservation planning. US Department of Agriculture, Agriculture Handbook, vol. 537, Washington DC, pp 85.

Yesuph, A.Y., Dagnew, A.B., 2019. Soil erosion mapping and severity analysis based on RUSLE model and local perception in the Beshillo Catchment of the Blue Nile Basin, Ethiopia. Environmental Systems Research 8, 17. https://doi.org/10.1186/s40068-019-0145-1 
Youe-Qing, X., Xiao-Mei, S., Xiang-Bin, K., Jian, P., Yun-Long, C., 2008. Adapting the RUSLE and GIS to model soil erosion risk in a mountains karst watershed, Guizhou Province, China. Environmental Monitoring and Assessment 141, 275-286.

Zeng, C., Wang, S., Bai, X., Li, Y., Tian, Y., Li, Y., Wu, L., Luo, G., 2017. Soil erosion evolution and spatial correlation analysis in a typical karst geomorphology using RUSLE with GIS. Solid Earth 8, 721-736. https:// doi.org/10.5194/se-8-721-2017
Zhang, Y.G., Nearing, M.A., Zhang, X.C., Xie, Y., Wei, H., 2010. Projected rainfall erosivity changes under climate change from multimodel and multiscenario projections in Northeast China. Journal of Hydrology $384,97-106$.

Zouagui, A., Benmansour, M., Amenzou, N. et al., 2012. Application la technique de $137 \mathrm{Cs}$ à l'estimation de l'érosion hydrique dans le bassin versant de Moulay Bouchta, Rif occidental, Maroc. Revue Marocaine des Sciences Agronomiques et Vétérinaires 1, 53-58. 